\title{
SHORT NOTE \\ New longevity record for the Mediterranean horseshoe bat (Rhinolophus euryale Blasius, 1853)
}

\author{
Carlos Ibáñez ${ }^{1,}{ }^{*}$, Roberto Novella-Fernandez ${ }^{2}$, Pedro Alonso ${ }^{3}$, Pablo T. Agirre-Mendi ${ }^{4}$
}

\author{
${ }^{1}$ Estación Biológica de Doñana \\ (CSIC), Avda Américo Vespucio \\ 26, 41092 Sevilla, Spain. \\ ${ }^{2}$ University of Southampton, \\ Life Sciences Building \\ 85 , Highfield Campus. \\ Southampton, SO17 1BJ, United \\ Kingdom. \\ ${ }^{3}$ Calle Río Alhama 9, 26300 \\ Nájera, La Rioja, Spain. \\ ${ }^{4}$ Paseo Río Grande 7, 3o - I, \\ 01320 Oyón, Álava, Spain. \\ *Corresponding author e-mail: \\ ibanez@ebd.csic.es \\ DOI: https://doi.org/10.14709/ \\ BarbJ.11.1.2018.09 \\ Keywords: Banding, \\ Chiroptera, longevity, lifespan, \\ Mediterranean horseshoe \\ bat, Rhinolophus euryale, \\ senescence, Spain, survival rate \\ received: June, 21st 2018 \\ accepted: September, 2nd 2018
}

\begin{abstract}
Bats have an unusually long lifespan among mammals, being at the end of the slow lane in the fast-slow continuum. In this note we report the recapture of a banded male individual of Rhinolophus euryale in La Rioja (Spain) with a minimum age of 21 years, representing a new longevity record for the species. We highlight that this is a case of long term fidelity of a male to a breeding colony, and we call attention to the apparent contradiction between the greater longevity found in male bats according to maximum lifespan records, compared to the higher mean lifespan and survival estimates that females show in demographic studies.
\end{abstract}

\section{RESUMEN}

Los murciélagos tienen una esperanza de vida inusualmente larga entre los mamíferos, y se encuentran en el extremo lento en el "continuo rápido-lento" de las historias de vida de los mamíferos. En esta nota, informamos la recuperación de un Rhinolophus euryale macho anillado en La Rioja (España) con una edad mínima de 21 años, lo que representa un nuevo récord de longevidad para la especie. Destacamos que este es un caso de fidelidad a largo plazo de un macho a una colonia reproductora y llamamos la atención sobre la aparente contradicción entre la mayor longevidad encontrada en murciélagos machos de acuerdo con los registros de máxima duración de vida, en comparación con la mayor esperanza media de vida y estimaciones de supervivencia que muestran las hembras en los estudios demográficos.
Longevity in mammals is positively related to body size, so for example elephants and whales reach ages much higher than mice or shrews. Bats are an exception to this general pattern, reaching ages 3.5 times higher than other mammals of their size (Austad \& Fischer 1991, Wilkinson \& South 2002). The longevity of bats is clearly related to other of their life history traits such as low fecundity (mostly one pup per year in temperate latitudes) or low mortality rates (Barclay \& Harder 2003). They also show no senescence in terms of survival rate and fertility until advanced age (Fleischer et al. 2017). Bats are thus, and despite their size, at the end of the slow lane in the "fast-slow continuum" of life histories of mammals (Barclay \& Harder 2003).

The maximum lifespan reported in bats was one individual of Myotis brandtii found in Siberia aged 41 years, being the longest lived known mammal in relation to its body size, with a lifespan 9.8 times longer than expected (Podlutsky et al. 2005). Other cases of species with known maximum ages exceeding 30 years include: Myotis myotis, 37 (Gaisler et al. 2003); Myotis lucifugus, 30-35 (Keen \& Hitchcock 1980, Davis \& Hitchcock 1995, Florko et al. 2017); Myotis blythii, 33 (Arlettaz et al. 2002); Rhinolophus ferrumequinum, 30.5
(Caubère et al. 1984), or Myotis daubentonii, 30 (Geiger \& Rudolph 2004 in Dietz et al. 2009). In this note we report a new longevity record for the Mediterranean horseshoe bat (Rhinolophus euryale), a mainly cave-dwelling bat.

The cave-mine Aradón, in the locality of Agoncillo (La Rioja, Spain) is roost for breeding colonies of R. euryale (70 individuals), Myotis emarginatus (70), R. ferrumequinum (25) and sporadically Myotis escalerai (census conducted in 2012). In addition, the presence of several dozen nonbreeding Miniopterus schreibersii is also frequent. On July 2, 2017 a banded male $R$. euryale was captured during a bat sampling session with a harp trap at the cave entrance, when returning after its nocturnal activity period. The band (code 2X08652), placed on the right forearm, was $3.0 \mathrm{~mm}$ internal diameter, Lambournes Ltd. (currently Porzana Ltd.) branded and anodized in green. Both the band and the forearm were found in perfect condition. The individual was released immediately after identifying the species and recording the band code because it was not the targeted species of the sampling. Details that could indicate senescence such as tooth wear could not be checked. 
According to the records of the Banding Comission of the Spanish Society for the Conservation and Study of Bats (SECEMU), the individual was banded in the same cave on the 12th of July 1997 by P. T. Agirre-Mendi. Since the individual was already an adult - and thus, at least one year old - when banded, by the time of the recapture reported in this note, the bat was aged a minimum of 21 years.

This record substantially extends previous records for the species; 13.5 and 10.5 years from a female and male respectively in the Carpathians (Uhrin et al. 2012), and 12.5 years in an Italian male (Crucitti 1976). In relation to other European rhinolophids, this new record is significantly lower than the $\mathbf{3 0 . 5}$ years for Rhinolophus ferrumequinum found in France (Caubère et al. 1984) and the 29.5 years for Rhinolophus hipposideros found in Czech Republic (Gaisler et al. 2003).

The male $R$. euryale reported in this note was the only individual banded on its sampling day in 1997, and it had never been recaptured. However, only a few bat samplings sessions have been carried out in the location since then, adding up less than 20 captures in total.

This case is unusual for being a male bat inidividual showing bat long fidelity to a nursery colony. Philopatry is a common feature in female bats which usually return to their natal colony every breeding season, whereas it is generally thought that males tend to disperse in this season (Carter \& Wilkinson 2013). Most longevity and long term fidelity cases reported in males are in hibernation roosts (Caubère et al. 1984, Podlutsky et al. 2005), although recently a case of long fidelity for a swarming roost in a male Myotis bechsteinii has been found in Italy (Bologna et al. 2018). The male fidelity for a maternity colony reported here could be explained because, unlike most temperate bats, nursery colonies of $R$. euryale tend to include many males (Ibáñez 1999).

Most longevity records of bats that exceed 20 years have been found in males, which seems to hold in few studies in which there is a certain sample size (Keen \& Hitchcock 1980, Caubère et al. 1984, Perkins 1994, Davis \& Hitchcock 1995, Arlettaz et al. 2002, Gaisler et al. 2003, Podlutsky et al. 2005, Florko et al. 2017), although there are also some exceptions (Lehmann et al. 1992, Harmata 1981, Brown 1989, Florko et al. 2017). In studies on bat demography and population dynamics, females usually show higher mean lifespan and annual survival rate estimates (Boyd \& Stebbings 1989, Gerell \& Lundberg 1990, Hoyle et al. 2001, Pryde et al. 2005, Papadatou et al. 2009, Schorcht et al. 2009, Ellison 2010, Humphrey \& Oli 2015, Culina et al. 2017), although some exceptions are also known (Keen \& Hitchcock 1980). The apparent contradiction in differential bat longevity depending on sex between maximum longevity records and demographic studies may be due to methodological artifacts in demographic studies produced by differences in behavior between both sexes (for example, females are more philopatric and more gregarious during reproduction), the existence of geographic variations (for instance, in Canada, M. lucifugus annual survival is higher in males, while in the US it is lower, Keen \& Hitchcock 1980), or simply that observed maximum longevity is not correlated with annual survival rate estimates (Krementz et al. 1989).
Therefore, we suggest that in bat demographic studies, mean lifespan and survival estimates should be used instead of longevity (O'Shea et al. 2011). Despite these limitations, longevity is of great interest in studies of the biology of aging and senescence (Wilkinson \& South 2002).

\section{ACKNOWLEDGEMENTS}

Fieldwork was funded through a University of Southampton start-up grant awarded to Orly Razgour, who we acknowledge. We also thank the regional Government of La Rioja (Spain) for providing the permits necessary to carry out the sampling and two anonymous reviewers for edits and comments on the manuscript.

\section{REFERENCES}

ARLETTAZ R., CHRISTE P. \& DESFAYES M. (2002). 33 years, a new longevity record for a European bat. Mammalia ,66(3):441-442. https://doi.org/10.1515/ mamm.2002.66.3.439.

AUSTAD S. N. \& FISCHER K.E. (1991). Mammalian aging, metabolism, and ecology: evidence from the bats and marsupials. Journal of Gerontology, 46(2): B47-B53. https://doi.org/10.1093/geroni/46.2.B47

BARCLAY R. M. R. \& HARDER L. M. (2003). Life histories of bats: life in the slow lane. In: Bat Ecology. University of Chicago Press, Chicago, EEUU, p. 209-253

BOLOGNAS., MAZZAMUTOM. V., MOLINARIA., MAZZARACCA S., SPADA M., WAUTERS L. A., PREATONI D. \& MARTINOLI A. (2018). Recapture of a banded Bechstein's bat (Chiroptera, Vespertilionidae) after 16 years: An example of high swarming site fidelity. Mammalian Biology, 91: 7-9. https://doi.org/10.1016/i.mambio.2018.03.001

BOYD I. L. \& STEBBINGS R. E. (1989). Population changes of brown long-eared bats (Plecotus auritus) in bat boxes at Thetford forest. Journal of Applied Ecology, 26: 101-112. http://www.jstor.org/stable/2403654

BROWN L. N. (1989). A longevity record for the little brown bat, Myotis lucifugus, in the Western States. Southwestern Naturalist, 34(2): 287-287. http://www. jstor.org/stable/3671742

CARTER, G. G. \& WILKINSON, G. S. (2013). Cooperation and conflict in the social lives of bats. In: Bat Evolution, Ecology, and Conservation. Springer Science+Business Media, New York, EEUU, p. 225-242.

CAUBÈRE B., GAUCHER P. \& JULIEN J. F. (1984). Un record mondial de longévité in natura pour un chiroptère insectivore? Revue d'Écologie (La Terre et la Vie), 39(3): 351-353. http://hdl.handle.net/2042/55173

CRUCITTI P. (1976). Interessanti ricatture di rinolofidi (Chiroptera) nella Grotta La Pila 71 La (Lazio). Doriana, 5: 1-59. 
CULINA A., LINTON D. M. \& MACDONALD D. W. (2017). Age, sex, and climate factors show different effects on survival of three different bat species in a woodland bat community. Global Ecology and Conservation, 12: 263271. https://doi.org/10.1016/j.gecco.2017.11.009

DAVIS W. H. \& HITCHCOCK H. B. (1995). A new longevity record for the bat Myotis lucifugus. Bat Research News, 36: 6.

DIETZ C., NILL D. \& VON HELVERSEN O. (2009). Bats of Britain, Europe and Northwest Africa. Black Publishers, London, United Kingdom, 400 pp.

ELLISON L. E. (2010). A retrospective survival analysis of Townsend's big-eared bat (Corynorhinus townsendii) from Washington State. Northwestern Naturalist, 91(2): 172-182. https://doi.org/10.1898/NWN09-10.1

FLEISCHER T., GAMPE J., SCHEUERLEIN A. \& KERTH G. (2017). Rare catastrophic events drive population dynamics in a bat species with negligible senescence. Scientific Reports, 7(1): 7370. https://doi.org/10.1038/s41598$\underline{017-06392-9}$

FLORKO K. R., BOHN S. J., KALCOUNIS-RUEPPELL M. C. \& BRIGHAM R. M. (2017). A 23-year-old little brown bat (Myotis lucifugus) record from Southwest Saskatchewan, Canada. Northwestern Naturalist, 98(1): 57-59. https:// doi.org/10.1898/NWN16-19.1

GAISLER J., HANAK V., HANZAL V. \& JARSKY V. (2003). Results of bat banding in the Czech and Slovak Republics, 1948-2000. Vespertilio, 7: 3-61.

GERELL R. \& LUNDBERG K. (1990). Sexual differences in survival rates of adult pipistrelle bats (Pipistrellus pipistrellus) in South Sweden. Oecologia, 83: 401-404. https://doi.org/10.1007/BF00317567

HARMATA W. (1981). Longevity record for the lesser horseshoe bat. Acta Theriologica, 26(34): 507.

HOYLE S. D., POPLE A. R. \& TOOP G. J. (2001). Mark-recapture may reveal more about ecology than about population trends: demography of a threatened ghost bat (Macroderma gigas) population. Austral Ecology, 26: 8092. https://doi.org/10.1111/i.1442-9993.2001.01092. pp.x

HUMPHREY S. R. \& OLI M. K. (2015). Population dynamics and site fidelity of the cave bat, Myotis velifer, in Oklahoma. Journal of Mammalogy, 96(5): 946-956. https://doi.org/10.1093/imammal/gyv095

IBÁÑEZ C. (1999). Rhinolophus euryale Blasius, 1853. In: The Atlas of European Mammals. Academic Press, London. 92-93 pp.
KEEN R. \& HITCHCOCK H.B. (1980). Survival and longevity of the little brown bat (Myotis lucifugus) in southeastern Ontario. Journal of Mammalogy, 61(1): 1-7. https://doi. org/10.2307/1379951

KREMENTZ D. G., SAUER J. R. \& NICHOLS J. D. (1989). Modelbased estimates of annual survival rate are preferable to observed maximum lifespan statistics for use in comparative life-history studies. Oikos, 56: 203-208. http://www.jstor.org/stable/3565337

LEHMANN J., JENNI L. \& MAUMARY L. (1992). A new longevity record for the long-eared bat (Plecotus auritus, Chiroptera). Mammalia, 56(2): 316-318. https://doi. org/10.1515/mamm-1992-0224

O'SHEA T. J., ELLISON L. E. \& STANLEY T. R. (2011). Adult survival and population growth rate in Colorado big brown bats (Eptesicus fuscus). Journal of Mammalogy, 92(2): 433-443. https://doi.org/10.1644/10-MAMM-A-162.1

PAPADATOU E., BUTLIN R. K., PRADEL R. \& ALTRINGHAM J. D. (2009). Sex-specific roost movements and population dynamics of the vulnerable long-fingered bat, Myotis capacinii. Biological Conservation, 142: 280-289. https:// doi.org/10.1016/i.biocon.2008.10.023

PERKINS J. M. (1994). Longevity records for two Vespertilionids. Bat Research News, 35:79-80.

PODLUTSKY A. J., KHRITANKOV A. M., OVODOV N. D. \& AUSTAD S. N. (2005). A new field record for bat longevity. Journal of Gerontology, 60(11): 1366-1368. https://doi.org/10.1093/gerona/60.11.1366

PRYDE M. A., O'DONNELL C. F. J. \& BARKER R. (2005). Factors influencing survival and long-term population viability of New Zealand long-tailed bats (Chalinolobus tuberculatus): implications for conservation. Biological Conservation, 126: 175-185. https://doi.org/10.1016/i. biocon.2005.05.006

SCHORCHT W., BONTADINA F. \& SCHAUB M. (2009). Variation of adult survival drives population dynamics in a migrating forest bat. Journal of Animal Ecology, 78(6): 1182-1190. https://doi.org/10.1111/j.1365-2656.2009.01577.x

UHRIN M., BOLDOGH S., BÜCS S., PAUNOVIC M., MIKOVA E., JUHÁSZ M., CSŐSZ I., ESTÓK P., FULÍN M., GOMBKÖTŐ P., JÉRE C., BARTI L., KARAPANDŽA B., MATIS Š., NAGY Z. L., SZODORAY-PARÁDI F. \& BENDA P. (2012). Revision of the occurrence of Rhinolophus euryale in the Carpathian region, Central Europe. Vespertilio, 16: 289-328.

WILKINSON G. S. \& SOUTH J. M. (2002). Life history, ecology and longevity in bats. Aging Cell, 1(2): 124-131. https:// doi.org/10.1046/i.1474-9728.2002.00020.x 